www.jmscr.igmpublication.org

Impact Factor 5.84

Index Copernicus Value: 83.27

ISSN (e)-2347-176x ISSN (p) 2455-0450

crossref DOI: _https://dx.doi.org/10.18535/jmscr/v5i5.92

Journal Of Medical Science And Clinical Research

\title{
Clinicopathological Profile \& Correlation of Tumor Size with Nodal Status in Oral Cavity Cancers: An AHRCC Experience
}

\author{
Authors \\ Samantaray Sagarika1, Pattanayak Lucy ${ }^{2}$, Panda Niharika ${ }^{3}$, Pathy Pramod ${ }^{4}$, \\ Panda Sanjoy ${ }^{5}$, Mohanty Lity ${ }^{6}$ \\ 1,3,4,6 MD, Associate Professor, ${ }^{2,5} \mathrm{MD}$, Assistant Professor \\ ${ }^{1}$ Department of Oncopathology, A.H.Regional Cancer Centre, Cuttack \\ ${ }^{2,3}$ Department of Radiation Oncology, A.H.Regional Cancer Centre, Cuttack \\ ${ }^{4,5}$ Department of Head and Neck Oncology, A.H.Regional Cancer Centre, Cuttack \\ ${ }^{6}$ Department of Pathology, SCB Medical College \& Hospital, Cuttack \\ Corresponding Author \\ Dr Lucy Pattanayak \\ 490/B,Santa Sahi,Canal Road, Bajrakabati, Cuttack, Orissa \\ Email: lucypattanayak2007@yahoo.co.in,Mob: 91-9937028362
}

\begin{abstract}
Head and Neck Squamous Cell Carcinomas are the most common cancers in India and the sixth most common worldwide. Oral Cavity cancers are most predominant malignancies in Head and Neck Cancers. Tumor size and extent of invasion is an important risk factor for nodal metastases, local recurrence and survival. The clinicopathological profile and correlation between the tumor size and nodal metastases in 235 patients of oral cavity cancers attending AH Regional Cancer Centre from January 2016 to January 2017 was analysed. All 235 patients were histopthologically proven squamous cell carcinoma of the oral cavity. The data base included age, sex, addictions, site, type of surgery and histopathogical details. The data of the primary tumor included size, differentiation, grade, depth of invasion, perineural and lymphovascular invasion.For the neck, the data included presence of metastases, size and number of involved nodes and extracapsular extension. A significant correlation between $T$ stage and $N$ stage was observed in the study. The primary tumor size is important in deciding management of the neck and volumetric assessment of tumor size along with thickness will help us to better define the nodal spread.

Keywords: Tumor size, Node, Oral Cavity, squamous cell carcinoma.
\end{abstract}

\section{Introduction}

Head and Neck Cancers are the most common cancers in India and the sixth most common cancer worldwide. ${ }^{(1)}$ Out of all the head and neck cancers, oral cavity cancers are the most common cancer in India with20 per 10,00,00 population being affected by oral cancer every year. ${ }^{(2)}$
Cervical Lymph Node metastases is the strongest prognostic factor for local relapse. Tumor size and extent of invasion is an important risk factor for nodal metastases, local recurrence and poor survival. The number and size of the involved lymph node and nodal characteristics like extranodal extension significantly influence 
regional recurrence, distant metastases and thereby survival. Besides clinicopathological features of primary tumors, the biological characteristics like lymphovascular invasion and perineural invasion also affect the aggressiveness of the tumor. ${ }^{(3)}$ The maximum tumor dimension and depth of invasion are considered the most important risk factor for lymph node metastases. ${ }^{(4)}$ The present study aimed to evaluate the clinical profile of oral cavity patients attending $\mathrm{AH}$ Regional Cancer Centre, Cuttack. It also aimed to correlate the primary tumor size (T stage) with the lymph node metastases ( $\mathrm{N}$ stage) in oral cavity cancers attending AH Regional Cancer Centre, Cuttack.

\section{Material Methods}

A total number of 235 patients of Oral Cavity Cancer attending AH Regional Cancer Centre, Cuttack from the period January 2015 to January 2016 were analysed for the study. All patients were histopathologically proven squamous cell carcinoma of oral cavity. A detailed history and comprehensive clinical examination was done followed by an appropriate surgical procedure. The database included age, sex, tumor size, tumor staging, histopathological data of primary tumor and cervical nodes. The histopathological data of the primary tumor included tumor type, differentiation, grade, lymphovascular invasion and perineural invasion. For the cervical node it included size, presence of metastases and extracapsular extension. A comparison was done between the primary tumor ( $\mathrm{T}$ stage) and the regional neck node metastases ( $\mathrm{N}$ stage).

\section{Results}

A total of 235 patients of histopathologically proven squamous cell carcinoma of oral cavity cancers were evaluated for the study. Age of the patients ranged from 22 years to 74 years with the mean age of presentation being 54.2 years. Majority of patients belonged to the $6^{\text {th }}$ decade i.e. 51 to 60 years followed by the $7^{\text {th }}$ decade i.e. 61 to 70 years as shown in Table 1:-

\begin{tabular}{|c|c|c|}
\hline $\begin{array}{c}\text { Age Range } \\
\text { (years) }\end{array}$ & $\begin{array}{c}\text { Number of } \\
\text { Patients }(\mathrm{n}=235)\end{array}$ & $\%$ \\
\hline $21-30$ & 4 & 1.70 \\
\hline $31-40$ & 15 & 6.38 \\
\hline $41-50$ & 34 & 14.46 \\
\hline $51-60$ & 125 & 53.19 \\
\hline $61-70$ & 55 & 23.40 \\
\hline $71-80$ & 2 & 0.85 \\
\hline
\end{tabular}

Males were the majority amounting to $83 \%$ $(n=195)$ while the rest $17 \%$ were females $(n=40)$ with a ratio of male to female of $5: 1$. The number of patients addicted to smoking were 134 (57\%) while 101 patients $(43 \%)$ patients were addicted to oral intake of tobacco and chewing paan.

Majority of the patients presented with growth in the buccal mucosa $(n=115 ; 48.9 \%)$ followed by $(\mathrm{n}=64 ; 27.2 \%)$ of patients with growth in the tongue. The site wise distribution of growth is shown in Table 2:-

\begin{tabular}{|c|c|c|c|}
\hline \multicolumn{2}{|c|}{ Site wise distribution } & $\mathrm{N}=235$ & $\%$ \\
\hline \multirow{4}{*}{ Site } & Buccal Mucosa & 115 & 48.9 \\
\cline { 2 - 4 } & Alveolus & 32 & 13.6 \\
\cline { 2 - 4 } & $\begin{array}{c}\text { Retromolar } \\
\text { Trigone }\end{array}$ & 17 & 7.23 \\
\cline { 2 - 4 } & Floor of mouth & 7 & 2.9 \\
\cline { 2 - 4 } & Tongue & 64 & 27.2 \\
\hline
\end{tabular}

The type of Surgery performed and the Neck Dissection done is shown in Table 3:-

\begin{tabular}{|c|c|c|c|}
\hline \multirow{2}{*}{ Surgery } & WLE & 147 & 62.5 \\
\cline { 2 - 4 } & Comprehensive & 88 & 37.4 \\
\hline \multirow{2}{*}{ Neck } & SOND & 133 & 0.43 \\
\cline { 2 - 4 } & MRND & 66 & 28.08 \\
\cline { 2 - 4 } & RND & 36 & 15.31 \\
\hline
\end{tabular}

WLE: wide local excision, SOND: supraomohyoid neck dissection, MRND: modified radical neck dissection, RND: radical neck dissection

The Histopathological characteristics are depicted in Table 4:-

\begin{tabular}{|l|c|c|}
\hline \multicolumn{2}{|l|}{ Histopathological characteristics } & $\begin{array}{l}\text { Number of Patients } \\
(\mathrm{n}=235)\end{array}$ \\
\hline Type of Tumour & scc & $235(100 \%)$ \\
\hline Differentiation & $\begin{array}{c}\text { Well } \\
\text { differentiated }\end{array}$ & $132(56.1 \%)$ \\
\hline & $\begin{array}{c}\text { Moderately } \\
\text { differentiated }\end{array}$ & $72(30.6 \%)$ \\
\hline & $\begin{array}{c}\text { Poorly } \\
\text { differentiated }\end{array}$ & $31(13.2 \%)$ \\
\hline Grade & G1 & $134(57.02 \%)$ \\
\hline & G2 & $74(31.4 \%)$ \\
\hline Tumour Size & G3 & $27(11.48 \%)$ \\
\hline & $<2 \mathrm{~cm}(\mathrm{~T} 1)$ & $12(5.10 \%)$ \\
\hline & $2-4 \mathrm{~cm}(\mathrm{~T} 2)$ & $25(10.63 \%)$ \\
\hline
\end{tabular}




\begin{tabular}{|l|c|c|}
\hline & Any size (T4) & $42(17.8 \%)$ \\
\hline Depth of Invasion & $<6 \mathrm{~mm}$ & $27(11.48 \%)$ \\
\hline & $6-10 \mathrm{~mm}$ & $92(39.14 \%)$ \\
\hline Stromal Interface & $>10 \mathrm{~mm}$ & $116(49.3 \%)$ \\
\hline & Deep Infiltrating & $111(47.2 \%)$ \\
\hline & Deep Pushing & $83(35.31 \%)$ \\
\hline Symphovascular & Infiltrating & $41(17.4 \%)$ \\
\hline Invasion & Positive & $75(31.9 \%)$ \\
\hline Margin & Negative & $160(68.08 \%)$ \\
\hline & Positive & $36(15.3 \%)$ \\
\hline Perineural Invasion & Negative & $199(84.6 \%)$ \\
\hline & Positive & $79(33.6 \%)$ \\
\hline Lymph Node size & Negative & $156(66.38 \%)$ \\
\hline & $<3 \mathrm{~cm}(\mathrm{~N} 1)$ & $42(17.8 \%)$ \\
\hline & $3-6 \mathrm{~cm}(\mathrm{~N} 2)$ & $50(21.27 \%)$ \\
\hline & $>6 \mathrm{~cm}(\mathrm{~N} 3)$ & $143(60.85 \%)$ \\
\hline
\end{tabular}

The Overall $\mathrm{T}$ and $\mathrm{N}$ status is depicted in Table 4:-

\begin{tabular}{|l|c|c|c|c|}
\hline & N1 & N2 & N3 & Total \\
\hline T1 & 6 & 4 & 2 & 12 \\
\hline T2 & 6 & 13 & 6 & 25 \\
\hline T3 & 37 & 45 & 74 & 156 \\
\hline T4 & 2 & 11 & 29 & 42 \\
\hline Total & 42 & 50 & 143 & 235 \\
\hline
\end{tabular}

\section{Discussion}

Head and Neck Cancer is the most common cancer in India and the sixth most common cancer worldwide. ${ }^{(1)}$ Out of all the head and neck cancers, majority of the patients present with lesions in the Oral Cavity.

Associations between the primary tumor ( $\mathrm{T}$ stage) with regional neck node ( $\mathrm{N}$ stage) has been extensively studied. In Oral Cavity cancers, the Lymph node metastasis is the most important indicator which increases the rate of distant metastases.

The present study aimed to correlate the $\mathrm{T}$ stage with the $\mathrm{N}$ stage in Oral Cavity Cancers. Besides the size of the primary tumor, the biology of the tumor like perineural invasion, lymphovascular invasion as well as the surgical procedure and margins influence the involvement of neck nodes. (5)

Patients of age group 21 to 80 years were evaluated for the study. The youngest patient was 22 years with a lesion in the buccal mucosa while the oldest patient was of age 74 years with a lesion in the lower alveolus. The mean age of presentation was 54.2 years. Studies in literature have also reported the mean age of presentation ranging from 59.3 years to 60.3 years. ${ }^{(6)}$ Majority of patients presented in the age range of 51 to 60 years. Review of literature reveals that the most common age range is in the $6^{\text {th }}$ decade. Majority of patients in our study presented in the 6th decade suggesting that oral cavity cancer is seen more in the elderly population. A study done by N.B. Ramachandra et al showed earlier presentation of head and neck cancer in the $3^{\text {rd }}$ to $4^{\text {th }}$ decade which is attributed to the consumption of tobacco. ${ }^{(7)}$

The ratio of male to female in the present study was $5: 1$. R.Shenoi et al showed a male to female ratio of $4.18: 1^{(8)}$ Other studies in the literature also reveal the male to female ratio of $4: 1$ to $5: 1$ which is in accordance with the present study. ${ }^{(9)}$

$57 \%$ of patients in our study were addicted to smoking while $43 \%$ were addicted to intake of oral tobacco and chewing paan. The distribution as per site revealed buccal mucosa to be the most commonly involved site (48.9 \%) followed by growth in the tongue $(27.2 \%)$ and the alveolus (13.6\%). In the study by N.B. Ramachandra et al, the most common subsite was buccal mucosa (57.8\%) followed by tongue (24.2\%). In another study by R. Shenoi et al buccal mucosa was seen in $23.3 \%$ followed by tongue in $18.31 \%$. ${ }^{(7,8)}$ These findings corroborate with those in the present study.

The analysis of distribution according to $\mathrm{T}$ stage revealed the most common stage to be $\mathrm{T} 3(\mathrm{n}=156$; $66.38 \%)$ followed by $\mathrm{T} 4 \quad(\mathrm{n}=42 ; 17.8 \%)$. Correlation of $\mathrm{T}$ stage with site showed that majority of patients of buccal mucosa presented with T3 and T4 lesions while majority of patients with lesions in the tongue presented in T2 and T3 stage. Studies from Akmansu at al and Pinnilla et al reveal that T3 is the commonest stage in lesions of the oral cavity. ${ }^{(10)}$ In distribution of the $\mathrm{N}$ stage, majority of patients had N3 stage $(n=143$; $60.85 \%)$, followed by N2 stage $(n=50 ; 21.28 \%)$ Correlation of primary tumor with the node 
revealed majority of tongue cancers with increased rate of lymph node metastases. ${ }^{(1)}$

The $\mathrm{T}$ stage (primary tumor) was correlated with the $\mathrm{N}$ stage. (Table 4) It shows that majority of patients with T3 and T4 status had increased propensity for neck node involvement. Out of 235 patients that were evaluated, $156 \quad(66.63 \%)$ patients of $\mathrm{T} 3$ and $42(17.8 \%)$ patients of $\mathrm{T} 4$ respectively had neck node metastases.N2 and N3 stage was seen predominantly with increasing $\mathrm{T}$ stage as shown in Table 4. This is in accordance with several studies in the literature which have shown a clear correlation between increasing tumor stage and risk of cervical node metastases (12). T1, T2 lesions have a risk of regional node metastases of 10 to $30 \%$ while $\mathrm{T} 3, \mathrm{~T} 4$ lesions have a much higher rate of involvement of regional neck nodes. ${ }^{(13,14)}$.

Conclusion: The present study highlights that buccal mucosa is the most frequently involved subsite in oral cancers. The size of the primary tumor ( $\mathrm{T}$ stage) correlates with the lymph node metastases ( $\mathrm{N}$ stage) and the $\mathrm{N}$ stage increases with increasing $\mathrm{T}$ stage. The primary tumor size is important in deciding management of the neck and volumetric assessment of tumor size along with thickness will help us to better define the nodal spread.

No source of support or grant declared.

No conflict of interest declared.

\section{References}

1. Shibuya K, Mathers CD,Boschi-Pinto C,et al. Global and regional estimates of cancer mortality and incidence by site; II. results for the global burden of disease 2000.BMC Cancer 2002;2:37.

2. Varshitha A,prevalence of Oral Cancer in India, J.Pharm Sci \& Res. Vol 7(10), 2015,845-48.

3. Cerezo L,Millan I,Torre A, Aragon G, Otero J. Prognostic factors for survival and tumor control in cervical lymph node metastases from head and neck cancer: a multivariate study of 492 cases. Cancer 1992; 69: 1224-34.

4. Moore C, Flynn MB, Greenberg RA. Evaluation of size in prognosis of oral cancer.Cancer.1986;58: 158-62

5. Chen TC, Wang CP, Ko JY, Yang TL,Hsu $\mathrm{CW}$,Yeh $\mathrm{KA}$ et al. The impact of perineural invasion and/or lymphovascular invasion on the survival of early stage oral squamous cell carcinoma patients. Ann Surg Oncol,2013;20:2388-95

6. Patel VA, Alastair LM, Fred R, et al. Advanced stage of head and neck cancer at a tertiary care county hospital. Laryngoscope 2006; 116(8): 1473-7

7. Ramachandra NB. The Hierarchy of Oral Cancer in India.Int $\mathbf{J}$ of Head and Neck Surg 2012;3(3):143-46

8. R Shenoi, V Devshukhkar, Chaudhuri, BK Sharma, SB Sapre, A Chikhale. Demographic and Clinical profile of oral squamous cell carcinoma patients: A retrospective study. Indian Journal of Cancer, 2012;49:21-6.

9. D’Souza O,Hasan S, Chary G, et al. Cervical metastasis in head and neck malignancy- a clinical/ultrasonographic/ histopthological comparative study. Indian Journal of ORL 2004;55(2):90-3.

10. Akmansu SH, Korkmaz H, Dursum E,et al. Clinical and histopthological indicators of neck node metastasis in laryngeal carcinoma. Tr J of Med Sci1999;29:313-7.

11. Pinilla M, Gonzale FM, Cortizo L, et al. Management of N0 neck in laryngeal carcinoma: impact on patient's survival. The Journal of Laryngology and Otology 2003;117(1):63-6.

12. Shah JP, Candela FC, Poddar AK. The patterns of cervical lymph node metastases from squamous cell carcinoma of the oral cavity. Cancer 1990;66:109-13

13. O' Brien CJ, Lauer CS, Fredricks S, Cliffor AR,Macneil EB, Baagia JS, Koulmandan C: Tumor thickness 
influences prognosis of $\mathrm{T} 1$ and $\mathrm{T} 2$ oral cavity cancer- but what thickness? Head Neck,25:935-945,2003

14. Ayas B, Saleem K, Azim W, Shaikh A: A clinicopathological study of oral cancers. Biomedica 27: 29-32,2011. 